\title{
エリミネータによる水滴の捕集
}

\section{Capture of a Droplet by the Eliminator}

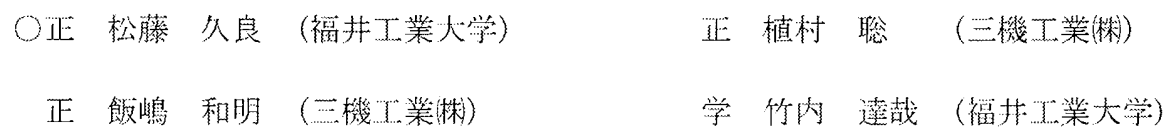

Hisayoshi Matsufuji, Tatsuya Takeuchi, Fukui University of Technology 3-6-1 Gakuen, Fukui-city, Fukui Pref., 910-8505 Japan

Satoshi Uemura, Kazuaki Iijima, Sanki Engineering Co.,Ltd

1742-7 Shimotsuruma, Yamato-city, Kanagawa Pref, 242-0001 Japan

1.はじめに

半導体用のクリーンルームでは空受中の水溶性の化学 物翼索除士寸るたかにコアワッシャ一が使われている。

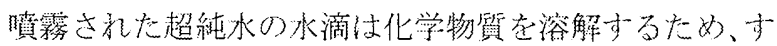

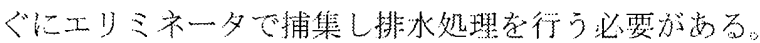

エリミネー夕は効率上く水滴を捕集できることや车力 椇失を少なく抽ることなよ゙が大切で、寒験による研究開発

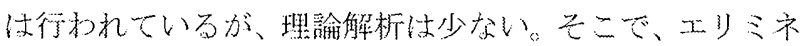
一夕の基整的な理諭解析を行うこしにする。

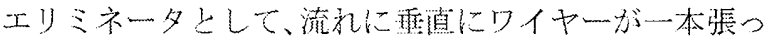
て亦場合老考える。ワイヤ一を月柱と考え、日柱周りの 流れをポテンシャル流れとして、円柱の上流から、気流と 闰じ速度で運動している粒子が円柱によ゙の上らな条件で 衝突するか在調心゙ることにする。

\section{2. 仮定}

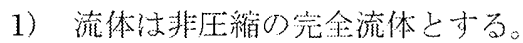

2）粒子注球形で小さく、流体からストークスの抵抗法 則定受ける无の上小る。

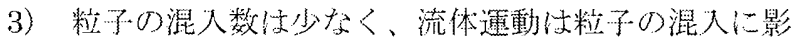

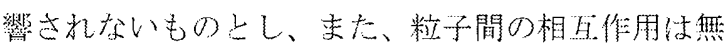
視古る。

4) 重力经門視する。

\section{2. 解析モデル}

図 1 に座標系老示括。

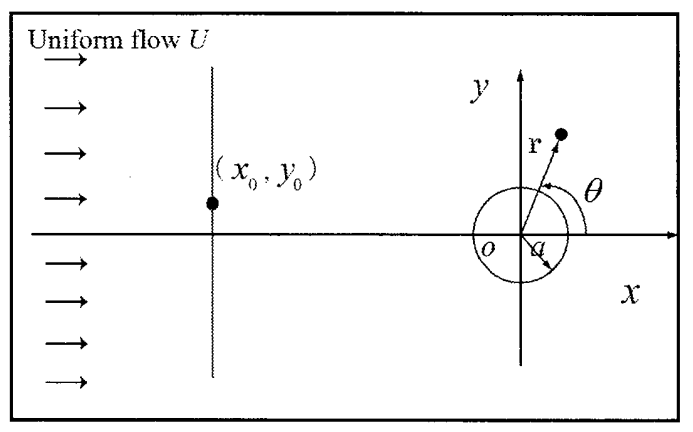

Fig. 1 Coordinates system

一様流中に丹桂加㚣万場合老考え\%。山杜の中心に原点

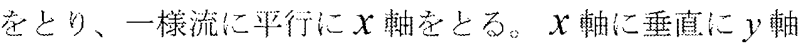

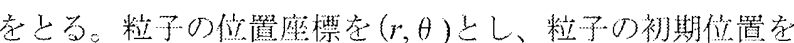

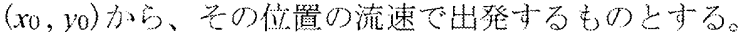

\section{4. 支配する方程式}

解䉼に市たり、速度は一様流の速度 $U$ の長さは円柱の

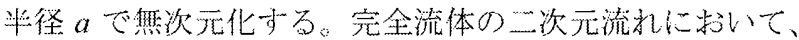

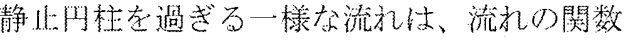

$$
\psi=\left(r-\frac{1}{r}\right) \sin \theta
$$

で与えられる。

粒子の運動方程式はニュートンの第…法則で記述され

$r$ 力问の粒子の運動力程式は、

$$
\frac{d^{2} r}{d t^{2}}-r\left(\frac{d \theta}{d t}\right)^{2}=\frac{1}{\sigma}\left(U_{t}-\frac{d r}{d t}\right)
$$

となる。ここでのはストークス数で、

$$
\sigma=\frac{2 R^{2} \rho_{\mathrm{p}} U}{9 \mu \mathrm{a}}
$$

でる。

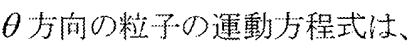

$$
\frac{d^{2} \theta}{d t^{2}}+\frac{2}{r} \cdot \frac{d r}{d t} \cdot \frac{d \theta}{d t}=\frac{1}{\sigma}\left(\frac{V_{f}}{r}-\frac{d \theta}{d t}\right)
$$

となる。

粒子の軌跡老定少す程式は、

$$
\begin{aligned}
& \frac{d r}{d t}=u \\
& \frac{d \theta}{d t}=\phi
\end{aligned}
$$

上策。

\section{5. 結果拉よび考察}

解析にあたり式(1)〜（6）をルンダクッタ法により数值 解老求めた。

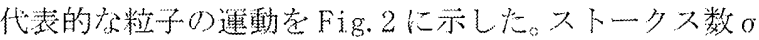
$=1.0$, 初期倍犆 $(-3,0.8)$ の場會在選んだ。参考のため初期 


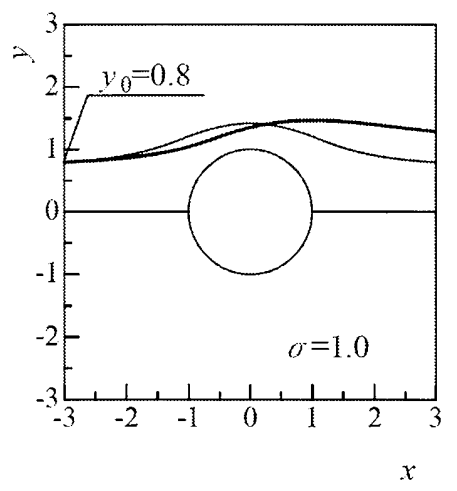

Fig.2 The trajectory of a particle

位置を通る流線を細線で示して㚣る。

粒子は流体之同じ初速度で出発したとしても、慣性力 があるため、流体の流れに対し曲線の外側にずれる。

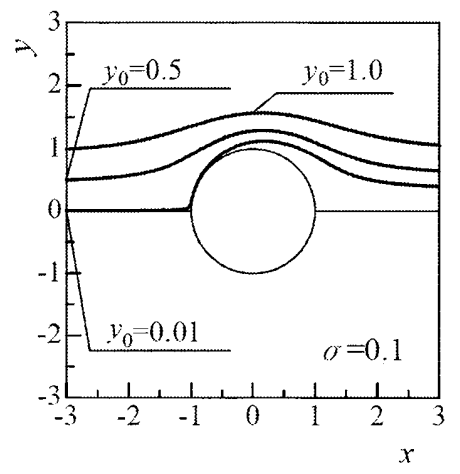

Fig.3 The trajectories of the particle in the case that $o=0.1$

粒子が円柱と衝器しない場会の粒子の隀跡在Fig. 3 に ホした。ストークス数 $\sigma=0.1$ 在選んだ場合、初期位犆 $y_{0}=0.01,0.5,1.0$ のとき示した。二の場合初期位嗔加

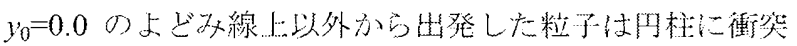
しない。

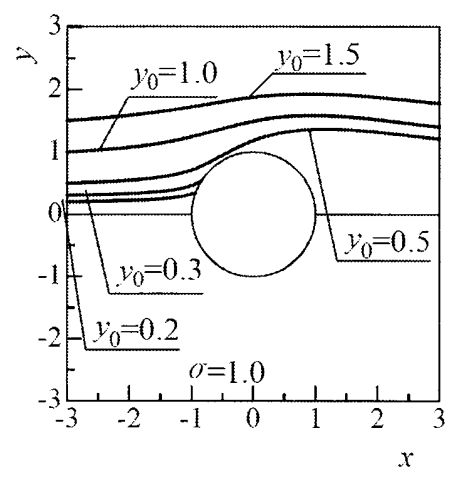

Fig.4 The trajectories of the particle in the case that $0=1.0$

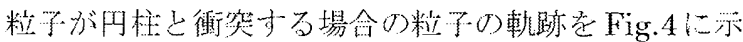
した。ストークス数 $\sigma=1.0$ 在選んだ Fig.4より、初期位

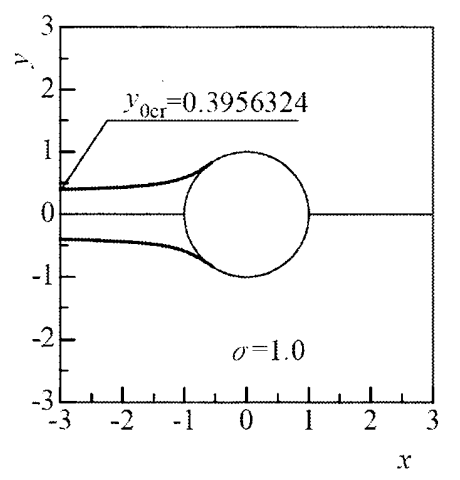

Fig.5 The trajectories of the particle in case of the critical initial position

置 $y_{0}=0.2,0.3$ 場合位衝管子るが、 $y_{0}=0.5,1.0,1.5$ の場会

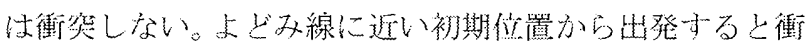
突し、離れた初期位置から思発すると衝突しないことがわ かる。このことより、备ストークス数に㸚して、y 方向の

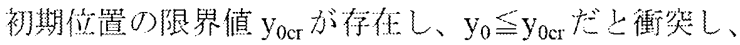
$\mathrm{y}_{0}>\mathrm{y}_{0 \mathrm{cr}}$ だと衝突しないことになる。

ストークス数 $\sigma=1.0$ のときの衝突限界の初期位置加ら

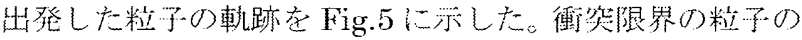

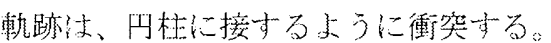

Fig.5で- $\mathrm{y}_{0 \mathrm{cr}} \leqq \mathrm{y}_{0} \leqq \mathrm{y}_{0 \mathrm{cr}}$ の範国から汁発した精子住川柱に

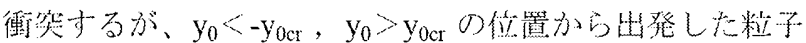
时衝營しない。

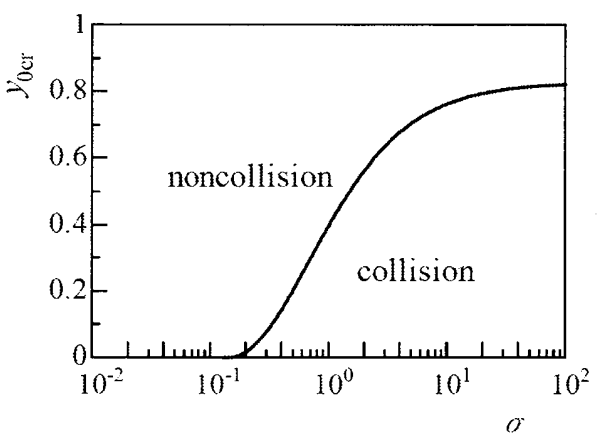

Fig.6 The critical curve for collision

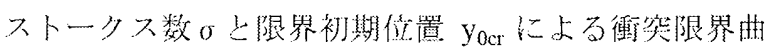
線をFig.6に示した。図の曲線の下僋が衝突領域で、上側

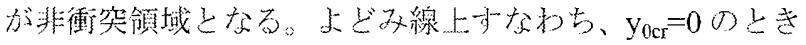
の徨突限界のストークス数は $0=0.125$ 上なる ${ }^{(2)}$

6. おわりに

エリミネータによる水滴の捕集哌究した結丞、ストーク 不数之初期位琶の衝突限界曲線が求まった。二の曲線より、 衝突寸万場合と衝突しない場合が明碓になった。

\section{参考文献}

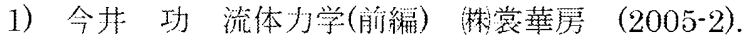

2) J.Val.Healy : THE PHYSICS OF FLUIDS, $13-3(1979-3)$, p. 551 